\title{
SEMANTIC ANALYSIS OF PASSIVE SENTENCE TRANSLATION IN NOVEL THE HUNGER GAMES: MOCKINGJAY BY SUZANNE COLLINS
}

\author{
Lionora Oktariani \\ lionora93@gmail.com \\ Universitas Negeri Jakarta \\ Endry Boeriswati \\ endry.boeriswati@unj.ac.id \\ Universitas Negeri Jakarta \\ Sri Harini Ekowati \\ sriharini@unj.co.id \\ Universitas Negeri Jakarta
}

\begin{abstract}
This study aims at analyzing the translation of English passive sentences into Indonesian language, in terms of the meanings and equivalence which appear in the translation. The method used to analyze the data is a descriptive quantitative. The sample of this research is taken from five chapters of the novel Hunger Games: Mockingjay by Suzanne Collins. The result shows that the translation of passive sentences comes into several types of meanings: lexical meaning $37 \%$, grammatical meaning $2 \%$, textual meaning $5 \%$, and contextual meaning $46 \%$. The translation of passive sentences also falls into two types of equivalences: formal equivalence $35 \%$ and dynamic equivalence $60 \%$. However, $5 \%$ belongs to no equivalent translation. In conclusion, the English passive sentences are mostly translated contextually so that the type of equivalence mostly appeared is dynamic equivalence. Hence, inventive ability, creativity, and experience are required to grasp the exact meaning of source text.
\end{abstract}

Keywords: Passive Sentences; Semantics; Equivalence; Translation; Novel.

Abstrak: Tujuan penelitian ini adalah untuk menganalisis terjemahan kalimat pasif
bahasa Inggris ke dalam Bahasa Indonesia dari segi makna dan kesepadanan yang
muncul. Metode yang digunakan untuk menganalisis data adalah metode deskriptif
kuantitatif. Sampel penelitian diambil lima bab dari novel The Hunger Games:
Mockingjay by Suzanne Collins. Hasil penelitian menunjukkan bahwa terdapat
beberapa jenis makna yang ditemukan dalam terjemahan kalimat pasif, yaitu makna 
leksikal sebanyak 37\%, makna gramatikal sebanyak $2 \%$, makna tekstual sebanyak $5 \%$, dan makna kontekstual sebanyak 46\%. Selain itu, ditemukan pula kesepadanan formal sebanyak 35\%, kesepadanan dinamis sebanyak $60 \%$, dan terjemahan yang tidak sepadan sebanyak 5\%. Dari hasil penelitian dapat ditarik kesimpulan bahwa kalimat pasif bahasa Inggris lebih banyak diterjemahkan secara kontekstual sehingga jenis kesepadanan yang banyak dihasilkan adalah kesepadanan dinamis. Hal ini menunjukkan bahwa kemampuan memahami makna, kreativitas, dan pengalaman diperlukan untuk menangkap makna dari teks sumber.

Kata Kunci: Kalimat Pasif; Semantik; Kesepadanan; Terjemahan; Novel.

\section{INTRODUCTION}

Translation, according to Oxford Advanced Learner's Dictionary (OALD), is rendering meaning of words or text from one language into another. Newmark (2001: 17) viewed translation as a process that involves comprehension and formulation; in the sense that while translating a translator did interpreting as well as recreating. The translator needs to comprehend the meaning both textual and beyond the text (Washbourne, 2012). Hatim and Munday (2004: 3) also viewed translation as a process and a product. As a process, translation refers to the role of the translator in taking the original or source text (ST) and turning it into a text in another language or target text (TT), and the product is the concrete translation produced by the translator. Furthermore, Hartono (2011: 6-7) has another idea that translation is an activity to read and grasp the meaning of the whole text by understanding words, phrases, clauses or sentences, and turn it into another language or target text (TT). In other words, all words, phrases, clauses or sentences in a text need to be understood to catch the ideas, thoughts, or intent of the author that are going to be translated. Thus, understanding of every single word, phrase, or clause in a text is very important for a translator.

Translation is also viewed as a process; it signifies that in translating, words, phrases or sentences are analyzed to find their meanings. The analysis of the meaning of individual words or phrases scientifically, according to Hatim and Munday (2004: 34), is called semantics. Semantics is the study of meanings of words and sentences (Saeed, 2016: 3). Words and sentences are studied semantically to have their meanings or the ideas of the writer. A sentence itself, as stated by Anker (2009: 313), has three elements: a subject, a verb, and a complete thought. A subject is a person, place, or thing that primarily acts, experiences, or described in a sentence. Verb is a word that tells what the subject does. A complete thought means the message or the idea of the writer. So as a process, translation has to do with the understanding of components of sentences: words, phrases, and sentences and the elements of sentences: subject, verb, and the meaning.

As previously stated, verb is one important thing that a translator has to concern. A verb in a sentence is closely related to the subject. Langan (2010: 586) states that both subject and verb are the basic building blocks of a sentence. Who or what the sentence speaks about is called a subject; what the sentence says about the subject is called a verb. He also adds that a verb has two types: active verb and passive verb; a sentence can have one of them. When the subject of a sentence receives the action of a verb, the verb is in the passive voice. The passive form of a verb consists of a form of the verb be plus the past participle of the main verb (Langan, 2010: 249). For example: The vanilla pudding was 
eaten by Tyra. So it is said that based on the types of the verb used, a sentence can be passive or active.

A passive sentence is constructed by subject plus be and past participle of main verb. It is different from an active sentence. Malamatidou (2013: 417) states that a passive sentence consists of subject - verb - (agent). It means that the use of an agent in a passive sentence is optional. Furthermore, Banks (2017: 2) states that a passive sentence can be used when someone does not want to mention the doer. Lastly, Bailey (2011: 231) states that, a passive sentence is usually used when the writer wants to focus on the result, not on the cause. From those statements, it can be concluded that the choice of type of a sentence is usually influenced by the purpose of the writer. Therefore, it is very crucial for a reader or particularly a translator to understand and translate well passive sentence into another language or target text (TT).

Concerning with the importance of the understanding of passive sentences for a translator, some researchers have conducted researches about passive sentences translation. Suprato (2013) has conducted a research about English passive sentences translation. She tries to find out how passive sentences are translated into Indonesian. The result shows that the structural changes or shifts in translating passive sentences into target text (TT) are truly unavoidable, since the translator has to preserve the ideas or the intention of the writer. Widya and Ayu (2015) also conduct a research about the translation of English passive sentences into Indonesian using semantic and grammatical approach. The analysis is limited to the three types of passive voices: present tense, past perfect tense, and modal auxiliary. They want to know whether some shifts occur in preserving the meaning of source text (ST). The result shows that cultural context and translation shift have an important role in creating a natural translation.

Based on the previous researches, it can be seen that the focus of the research about passive sentence translation is just on the change of the structure or shifts in maintaining the meaning or the ideas of the writer. Little attention is given to passive sentence translation analysis that focuses on the meaning appeared in translation in which every word, phrase, and sentences are analyzed semantically. Furthermore, the analysis of meaning in translation also closely related to the translation equivalence. According to Nord in Putra (2017: 85) equivalence is a concept of corresponding ideas between ST and TT. Nida and Taber in Venuti (2012: 149-151) states that there are two kinds of equivalences in translation. They are formal equivalence and dynamic equivalence. Formal equivalence focuses on form in translating ST into TT. Every word in ST is translated literally, so a verb is translated with a verb, a noun is translated with a noun, etc. On the contrary, dynamic equivalence focuses on meaning. In dynamic equivalence, the meaning or the author's intention is preserved so that the change of form is unavoidable. Related to the meaning appears in translation, Suryawinata (1989: 21-24) proposes five kinds of meanings in translation. They are lexical meaning, grammatical meaning, textual meaning, contextual meaning, and sociocultural meaning. Lexical meaning is a meaning of a word as written in a dictionary. Textual meaning is a meaning by its reference or connotative meaning. Contextual meaning is a meaning which depends on the context. Sociocultural meaning is a meaning that depends on social and cultural factors.

Therefore, in this research, the analysis is focused on how the translator translates the English passive sentences as ST into Indonesian language as TT especially in novel The Hunger Games: Mockingjay by Suzanne Collins translated by Hetih Rusli. The writer wants to know what types of meanings appear in the translation. Moreover, the writer also 
wants to know whether passive sentences are translated well into the target language or target text (TT); in the sense that the ideas conveyed by the translator are really equivalent or not with the ideas intended by the ST writer. It is important to know in doing translation, since every small meaningful unit in a sentence will affect the meaning of a sentence and the whole text.

\section{METHOD}

The data of the research are passive sentences that are taken from a novel titled The Hunger Games: Mockingjay written by Suzanne Collins and published by Scholastic America and its translation by Hetih Rusli which published by Gramedia Pustaka Utama Jakarta. To get the data, the writer uses a random sampling technique. The total sample of this research is $20 \%$ out of 27 chapters. So, the chapters used to take the data are chapter 2 , $3,16,17$, and 26 . To analyze the data, the writer uses a descriptive quantitative method in which English passive sentences are described quantitatively using percentage. The steps in analyzing data, the writer refers to Miles and Huberman Analysis (Putra, 2013: 204). Firstly, passive sentences are identified and underlined. Secondly, those passive sentences are analyzed and classified according to the types of meanings and the equivalences. Thirdly, based on the classification of their meanings and equivalences, passive sentences are counted and put into percentage. Lastly, the results are discussed and conformed with the experts' statements to validate the findings.

\section{RESULT AND DISCUSSION}

Referring to the aims of the research, the writer wants to find out the types of meanings and the equivalences from English passive sentence translation in novel The Hunger Games: Mockingjay written by Suzanne Collins and its translation by Hetih Rusli. All data of the research are collected from five chapters, i.e. chapter $2,3,16,17$, and 26 . The amount of passive sentences that have been found and collected is 83 items. Those passive sentences are analyzed and classified according to the types of meanings and its equivalence. Each type of meaning and equivalence contained in a passive sentence translation is discussed in accordance with the experts' statements.

\section{Types of Meanings}

Based on the result of the analysis, there are four types of meanings appear in the passive sentence translation. They are lexical meaning, grammatical meaning, textual meaning, and contextual meaning. The number and percentage of each type of meaning is presented in table 1 .

Tabel 1. Types of Meanings

\begin{tabular}{cccc}
\hline No & Meaning & Number & Percentage (\%) \\
\hline 1 & Lexical Meaning & 30 & $37 \%$ \\
\hline 2 & Grammatical Meaning & 2 & $2 \%$ \\
\hline
\end{tabular}


Oktariani, Boeriswati, Ekowati, Semantic Analysis of Passive Sentence Translation | 136

\begin{tabular}{cccc}
\hline No & Meaning & Number & Percentage (\%) \\
\hline 3 & Textual Meaning & 5 & $6 \%$ \\
\hline 4 & Contextual Meaning & 46 & $55 \%$ \\
\hline & Total & $\mathbf{8 3}$ & $\mathbf{1 0 0 \%}$ \\
\hline
\end{tabular}

From the table 1 , it can be seen that the number of lexical meaning is $37 \%$. It shows that $37 \%$ of passives sentences found in the novel are translated literally. Next, the number of grammatical meaning is only $2 \%$. It indicates that there are a few of passive sentences which their verbs are changed. Some verbs in passive form are changed into the active ones due to grammatical rules of TT. The change is unavoidable since the exact meaning of the ST or the author's ideas has to be preserved. Then, the number of textual meaning is $6 \%$. It means that there are several passive sentences in which the meaning is determined by its reference. Lastly, the number of contextual meaning is 55\%. It shows almost more than half of the passive sentences collected are translated according to the situation described in the text. Here are given the analysis of passive sentences related to the types of meanings.

\section{Type 1}

\section{Lexical Meaning}

ST: In the silence that follows, I notice the lines that have formed between Peeta's eyebrows. He has guessed or he has been told. (p. 22)

TT: Dalam keheningan setelah itu, aku memperhatikan garis-garis yang terbentuk di antara kedua alis Peeta. Dia sudah menebak atau dia sudah diberitahu. (p. 29)

In the sentence above, a word told is a past participle form of a verb tell. Semantically, according to OALD, word tell can be know. In bahasa Indonesia, word know means tahu. Regarding to the English passive sentence, the sentence he has been told belongs to Perfect Tense in which something happens at unspecified time in the past (Azar, 2003: 86). Next, auxiliary has that is followed by (to be) been and past participle told signifies a passive sentence. It highlights on the action rather than the doer, and the subject is acted upon. It reflects the objectivity and impersonality of passive sentences (Rodriguez and Vergara, 2017:2). Thus, the phrase has been told is translated into sudah diberitahu. Prefix disignifies a passive form of a verb in bahasa Indonesia. Therefore, the prefix $d i$ - here is called as non-actor voice in which the doer is prevented from being known (Arka, 2012:21). As a result, the subject and the verb in the ST is translated according to its function and meaning; it becomes dia sudah diberitahu. Referring to Suryawinata's statement (1989), it can be said that the meaning found belongs to lexical meaning. 


\section{Type 2}

\section{Grammatical Meaning}

ST: No one notices me, though, because they're all gathered at a television screen at the far end of the room that airs the Capitol broadcast around the clock. (p. 20)

TT: Akan tetapi tak ada seorang pun yang memperhatikanku karena mereka semua berkumpul di layar televisi di ujung ruangan yang menyiarkan acara Capitol selama 24 jam. (p. 28)

In the sentence above, word gathered is a past participle form of a verb gather. Semantically, according to OALD, word gather means bring people together into a place. In bahasa Indonesia, word gather means berkumpul. Word berkumpul means bersamasama menjadi satu kesatuan atau kelompok (KBBI online). In other word, word berkumpul means people are coming together to certain place.

Verb gathered which is preceded by are signifies a passive sentence in English. Passive sentence usually highlights on the action rather than the doer, and the emphasis is on the receiver of the action (Anker, 2010: 395). In this translation, phrase are gathered is translated into berkumpul on the purpose of getting the exact meaning of the translation. The translator here uses prefix ber-instead of $d i$-. It proves that the translator's inventive ability and creativity is very crucial in the process of translation (Sajarwa, 2017: 167). It can be seen that affixation affects the meaning of a word as well as a whole sentence. In this case, a correct form of a verb berkumpul should be used to convey a clear meaning or idea of the ST writer. Referring to Suryawinata's statement (1989), here it is found that the meaning appears belongs to grammatical meaning.

\section{Type 3}

\section{Textual Meaning}

ST: We've been funneled into a class of relative beginners, fourteen-or fifteen-yearolds, which seems a little insulting until it's obvious that they're in far better condition than we are. (p. 235)

TT: Kami didaftarkan pada kelas pemula, anak-anak empat belas atau lima belas tahun, yang sepertinya menghina kami sampai kemudian terlihat bahwa kondisi mereka jauh lebih baik daripada kami. (p. 256)

In the sentence above, semantically, word funnel as a noun refers to a tool which has a wide top and a narrow bottom which is used for pouring liquids or powders; as a verb it means to move something through a narrow space (OALD). In bahasa Indonesia, word funnel means corong. Corong means alat berbentuk kerucut yang digunakan untuk menuang cairan (KBBI online).

Concerning to the passive sentence translation, verb funnel preceded by phrase have been signifies a passive sentence. However, the translation of the word funnel does not correspond to its meaning in the dictionary. It is translated based on its relationship with other words in the sentence, so its meaning is determined by its reference or connotative, i.e. an act to enroll someone to a certain course. In this translation, the translator tries to disclose the meaning based on the information provided by words in the sentence on the 
purpose of getting the exact meaning (Widya and Ayu, 2015:130). That's why doing translation may not always be appropriate with the target language as stated by Nida and Taber in Sajarwa (2017: 159). Thus, phrase have been funneled is translated into didaftarkan. Confix di-kan signifies a passive sentence. Passive sentence highlights on the action rather than the doer, and the subject is acted upon. According to Suryawinata's statement (1989), the meaning found in the sentence is textual meaning.

\section{Type 4}

\section{Contextual Meaning}

ST: Trailing a few steps behind Gale, I try to collect myself, before I'm thrown into what's sure to be another relentless Mockingjay session. (p. 20)

TT: Aku berjalan beberapa langkah di belakang Gale, berusaha menenangkan diri sebelum masuk ke sesi Mockingjay yang tak berujung. (p. 27)

In the sentence above, phrase thrown into is a past participle form of a phrasal verb throw into. According to OALD, phrase thrown into means start doing something with energy and enthusiasm. In bahasa Indonesia, phrase thrown into means memulai sesuatu dengan semangat dan antusias.

In this case, the meaning of the phrase thrown into does not correspond to the dictionary. It is translated into begins something reluctantly since the clause I try to collect myself implies that $I$, the main character, join the Mockingjay session unwillingly. The phrase thrown into is not translated by its meaning in the dictionary; this way is used to deliver the exact meaning or the idea of the ST writer. It is seen that the translation done by the translator is based on the context and situation. In other words, the translation is done by the use of contextual clues by which the translator tries to grasp the idea of the sentence (Widya and Ayu, 2015: 130). Thus, the phrase thrown into is translated into masuk. Word masuk is an active form of verb which highlights on the doer rather than the action. Thus, in line with Suryawinata's statement (1989), the meaning found in this sentence is contextual meaning.

\section{Equivalence}

According to Nida and Taber in Venuti (2012), there are two kinds of equivalences, i.e. formal equivalence and dynamic equivalence. Formal equivalence means every word in ST is translated literally, so a verb is translated with a verb, a noun is translated with a noun, etc., whereas dynamic equivalence focuses on meaning. In dynamic equivalence, the meaning or the ST writer's intention is preserved so that the change of form is unavoidable. Based on the result of the data analysis, it is found that formal equivalence and dynamic equivalence appear in this passive sentence translation. However, four translations found are considered not belong to both formal and dynamic equivalences. The translations do not carry the exact meaning intended by the ST writer. The number and percentages of each equivalence are presented in table 2 . 
Table 2. Equivalences

\begin{tabular}{clcc}
\hline No & Equivalence & Number & Percentage (\%) \\
\hline 1 & Formal & 29 & $35 \%$ \\
\hline 2 & Dynamic & 50 & $60 \%$ \\
\hline 3 & No equivalent & 4 & $5 \%$ \\
\hline & Total & $\mathbf{8 3}$ & $\mathbf{1 0 0 \%}$ \\
\hline
\end{tabular}

From the table 2, it can be seen that the number of dynamic equivalence is $60 \%$. It means that many changes, mainly in function, happen in order to preserve the original idea of ST conveyed by the writer. Next, the number of formal equivalence is $35 \%$. It indicates that $35 \%$ of passives sentences translation are correspond formally in terms of its function and meaning. Lastly, the number of no equivalent translation is only $5 \%$. It means that only few translations do not carry the exact meaning of the ST. Here are given the analysis of passive sentences related to the equivalences.

\section{Formal Equivalence}

ST: When that wire was cut, everything just went insane. (p. 24)

TT: Saat kawat terputus, semuanya menggila. (p. 31)

In ST system, a passive sentence is formed by be plus verb past participle. In TT system, a passive sentences is formed by affixation, for instance, prefix $d i$ - and ter- that is attached to a verb. Looking at the passive sentence translation above, the verb in ST is translated literally. A passive sentence in ST is also translated into a passive one in TT. Next, word cut in OALD means to remove something or a part of something using a knife, etc. According to KBBI online, word putus means tidak bersambung lagi karena terpotong or no longer connected to something. In this case, the meaning of word cut corresponds to the word putus. It can be seen that the phrasal verb in ST and TT are similar either in meaning or form. Phrasal verb was cut corresponds formally to the TT verb i.e. terputus. A translation can be said to have a formal equivalence when a grammatical category in TT occupies the same position as the category in the ST system (Widya and Ayu, 2015: 127). Thus, in line with Nida and Taber's statement in Venuti (2012), this passive sentence translation belongs to formal equivalence.

\section{Dynamic Equivalence}

ST: You're too caught up in Beete's plan to electrify the salt lake. (p. 23)

TT: Kau terlalu sibuk dengan rencana Beete untuk menyetrum danau air asin itu. (p. 31)

The phrasal verb are caught up in ST above is a stative passive. Stative passive refers to a certain situation. In this translation, the translator makes a change to get the exact meaning or the idea of the writer. The meaning produced by the translator is influenced by 
the situation described in the text. Cronin in Sajarwa (2017: 159) asserts that obtaining the equivalence in translation tends to be more creative and situational. As a result, the phrasal verb are caught in ST is converted into adjective in TT, so phrasal verb caught up becomes sibuk. Sibuk in TT belongs to adjective. Thus, in line with Nida and Taber's statement in Venuti (2012), this passive sentence translation belongs to dynamic equivalence.

\section{No equivalent Translation}

As previously stated, some translations are found not belong to either formal or dynamic equivalences. Here is an example of a no equivalent translation.

ST: This wasn't part of the plan. I wrote Peeta off in 2. Then I was to go to the Capitol, kill Snow, and get taken out myself. (p. 229)

TT: Ini bukanlah bagian dari rencana. Aku sudah mencoret nama Peeta di Distrik 2. Kemudian aku akan ke Capitol, membunuh Snow, dan membiarkan diriku ditangkap. (p. 250)

The phrasal verb get taken out in ST above is a passive sentence that highlights on the action. According to OALD, phrasal verb get taken out means to kill somebody or destroy something. In bahasa Indonesia, it means membunuh seseorang atau menghancurkan sesuatu. However, in TT, the phrase get taken out is translated into ditangkap. It is better to be translated into menyerahkan diri. Menyerahkan diri means she has an intention to surrender. Whereas, ditangkap means someone will catch her after killing Snow. This is a no equivalent translation, since the passive sentence translation doesn't refer to either formal or dynamic equivalence. In this case, the translation does not carry the exact meaning as intended by the ST writer. For this reason, inventive ability, creativity, and experience play an important role in grasping the exact meaning of ST (Sajarwa, 2017: 167).

\section{CONCLUSION}

When translation is viewed as a process, it signifies that every word, phrase, or clauses is examined scientifically to get the exact meaning or the idea of the ST writer. In this case, a translator has an important role in taking the original or source text (ST) and turning it into a text in another language or target text (TT). In other words, every word, phrase, clause or sentence has to be analyzed semantically to catch the ideas, thoughts, or the intent of the writer.

In doing translation, there are two things that have to be considered, i.e. meanings and equivalences. For this reason, this research is focused on how the translator of the novel Hunger Games: Mockingjay translates passive sentences into Indonesian language. It is found that there are four types of meanings appear in the translation, i.e. lexical meaning, grammatical meaning, textual meaning, and contextual meaning. There are also two types of equivalences found in the English passive voice translation, i.e. formal equivalence, dynamic equivalence. However, there are also few translation that do not belong to either formal or dynamic equivalence. They are called as no equivalent translation.

Regarding to the types of meanings, each type of meaning has its own criteria to which it belongs. The first type is lexical meaning in which the phrasal verb in the passive 
sentence is translated according to its function and meaning; every word from ST is translated into TT literally. This kind of translation takes 37\%. The second type of meaning appeared is grammatical meaning. This type of meaning takes only $2 \%$. It means that few phrasal verbs in passive sentences are translated by making grammatical changes. The changes made here is to maintain the idea of the ST writer. The next type of meaning is textual meaning; it takes $6 \%$. Textual meaning indicates that a translator can get the exact meaning of the phrasal verbs by considering the text in terms of its reference or connotative meaning. The last type is contextual meaning which has the highest percentage; it takes $55 \%$. It shows that many passive voices are translated based on the context and situation described in the text to get the exact meaning of the ST writer.

Regarding to the types of equivalence, each type of equivalence also has its own criteria. The first is formal equivalence in which ST is translated literally into TT. This type of equivalence takes $35 \%$. The next is dynamic equivalence in which several changes are done by the translator on purposes of maintaining the exact meaning or the writer's intention in ST. This type equivalence takes $60 \%$. The last is the no equivalent translation which does not correspond both formally or dynamically. It takes only $5 \%$. It means only few translations that do not carry the exact meaning or the ST writer's intention. All in all, the translation of passive sentences here are translated contextually and inclined towards dynamic equivalence. It is done by the translator due to having agreement in meaning and acceptable in TT system.

\section{REFERENCES}

Anker, S. 2010. Real Writing with Readings: Paragraph and Essays for College, Work, and Everyday Life. New York: Bedford/St. Martin's.

Arka, I. W. 2012. Developing a Deep Grammar of Indonesian within the ParGram Framework: Theoretical and Implementational Challenges. Information and Computation, http://www.researchgate.net/publication/289789337.

Azar, B.S. 2003. Fundamentals of English Grammar. New York: Longman.

Bailey, S. 2011. Academic Writing: A Handbook for International Students London: Routledge.

Banks, D. 2017. The Extent to Which Passive Voice is Used in the Scientific Journal Article, 1985-2015. Functional Linguistics, 4:12. https://doi.org/10.1186/s40554-0170045-5.

Collins, S. 2010. The Hunger Games: Mockingjay. New York: Scholastic Inc.

Badan Pengembangan dan Pembinaan Bahasa. 2018. Kamus Besar Bahasa Indonesia (KBBI) daring.https://www.kbbi.web.id.

Hartono, R. 2011. Teori Penerjemahan: a Handbook for Translator. Semarang: CV Cipta Prima Nusantara Semarang.

Hatim, B. Munday, J. 2004. Translation: An Advanced Resource Book. New York: Routledge Taylor \& Francis Group.

Hornby, A.S., Wehmeier, S., McIntosh, C., Turnbull, J., Ashby, M. 2005. Oxford Advanced Learner's Dictionary. Oxford: Oxford Univ. Press.

Langan, J. 2010. Exploring Writing: Sentences and Paragraphs. New York: MacGrawHill. 
Malamatidou, S. 2013. Passive Voice and the Language of Translation: A Comparable Corpus-Based Study of Modern Greek Popular Science Articles. Meta, 58(2), 411-429. doi:10.7202/1024181ar

Newmark, P. 2001. Approaches to Translation. Oxford: Pergamon Press.

Putra, N. 2013. Penelitian Kualitatif: Proses dan Aplikasi. Jakarta: PT Indeks.

Putra, P.P. 2017. Penerjemahan Bahasa Inggris-Indonesia. Yogyakarta: Pustaka Pelajar.

Rodriguez, D., Vergara. 2017. A Systemic Functional Approach to the Passive Voice in English into Spanish Translation: Thematic Development in a Medical Research Article. Open Linguistics, Volume 3, 1-17.

Rusli, H. 2014. The Hunger Games: Mockingjay. Jakarta: PT Gramedia.

Saeed, J. I. 2016. Semantics. New Delhi: Wiley Blackwell.

Suprato, D. 2013. Analisis Penerjemahan Kalimat Pasif Bahasa Inggris ke dalam Bahasa Indonesia pada Novel Morning, Noon, and Night Karya Sidney Sheldon. Lingua Cultura, 7(1), 49-56.

Sajarwa, 2017. Deconstructing equivalence in the Translation of Texts from French to Indonesian. HUMANIORA, Volume 29, 159-168.

Suryawinata, Zuchridin. 1989. Terjemahan: Pengantar Teori dan Praktek. Jakarta: Depdikbud.

Venuti, Lawrence. 2012. Translation Studies Reader. New York: Routledge.

Washbourne, Kelly. 2012. Active, strategic reading for translation trainees: Foundations for transactional Methods. Translation \& Interpreting, 4(1), 38-55.

Widya and Ayu D. M. I. 2015. Translation of Passive Voice Found in the Novel The Sea of Monster by Rick Riordan and Its Translation by Nuraini Mastura. Lingua Cultura, 9 (2), 126-131. 